\title{
Slavery Today and Its Social Impact
}

\section{Enrique Vázquez Fernández', Danae Duana Avila2*, Víctor Hernández Bautista3, María Guadalupe Cruz García ${ }^{1}$, Olga Anaid Díaz Jacinto ${ }^{1}$}

\author{
${ }^{1}$ Universidad Autónoma del Estado de Tlaxcala, Tlaxcala, México \\ ${ }^{2}$ Universidad Autónoma del Estado de Hidalgo, Pachuca de Soto, Hidalgo, México \\ ${ }^{3}$ Universidad de la Sierra Juárez, Ixtlán, Juárez Oaxaca, México \\ Email: ^duananos@yahoo.com.mx,duana@uaeh.edu.mx
}

How to cite this paper: Fernández, E. V., Avila, D. D., Bautista, V. H., García, M. G. C., \& Jacinto, O. A. D. (2020). Slavery Today and Its Social Impact. Advances in Applied Sociology, 10, 61-73. https://doi.org/10.4236/aasoci.2020.103005

Received: June 20, 2019

Accepted: March 23, 2020

Published: March 26, 2020

Copyright $\odot 2020$ by author(s) and Scientific Research Publishing Inc. This work is licensed under the Creative Commons Attribution International License (CC BY 4.0).

http://creativecommons.org/licenses/by/4.0/

\begin{abstract}
This research seeks to explain in a complete way the main causes and consequences of modern slavery in real life. This use mainly affects society; millions of people are subject to modern forms of slavery, mostly women and children. We cannot limit ourselves to African slavery because today slavery lurks around us: on the one hand, the other systems of services and services, on the other hand, the sale and illegal trafficking of people, Traffic where the main ones, although not exclusive, victims of children, the poor, women and immigrants. Its most frequent activities are forced labor in agriculture and industries, prostitution, pornography, drug trafficking, theft, domestic work.
\end{abstract}

\section{Keywords}

Slavery, Society, Work

\section{Introduction}

\section{The Slavery in Mexico}

The exact number of slaves in northern America at the time of the insurrection that Miguel Hidalgo and Ignacio Allende led in September 1810 is not known with precision. According to some estimates there were between nine and ten thousand men and women in this territory captivity.

On the issue of slavery there is a wide historiography produced by Mexican and foreign historians, who analyze the practice of this practice from the sixteenth century until the expedition of the side of December 6, 1810 where its abolition was declared, implying that since then there were no slaves in Mexico.

As Hidalgo and the other insurgent leaders never had control over all of the territory of New Spain, nor was their authority recognized, the sides that issued the issue were not respected by all the slave owners.

In the independent Mexico, during the governments of Victoria and Guerre- 
ro, decrees of abolition were issued again, but indemnifying the owners so as not to affect the right of property; subsequently, the Executive once again suppressed it, which indicates that this issue continued into the 19th century. To eradicate this practice, it was necessary to record its abolition in the federalist and centralist Constitutions, even in the 1917 Constitution.

The slavery towards the indigenous races was lived in a practically inhuman way during the conquest stage, since the Spaniards believed themselves with the right to own the towns as one of their belongings.

Although slavery has existed since antiquity, the first international instrument that condemned this practice was the Declaration of 1815 concerning the universal abolition of the slave trade (the "Declaration of 1815 ").

The abolitionist movement began with the aim of putting an end to the slave trade in the Atlantic and freeing the slaves in the colonies of European countries and in the United States of America. There are a large number of multilateral and bilateral agreements that date back to the early 19th century and contain provisions prohibiting such practices in time of war and peace. It has been estimated that between about 1815 and 1957 some 300 international agreements concerning the abolition of slavery were applied. None of them has been totally effective.

\section{Problem Statement}

Slavery is a broad issue that manifests itself in different ways; the best known could be related to the modes of production that existed 500 years ago.

The slavery of people is born with the need to do heavy work without paying for such service. There are other types of slavery nowadays, it can be observed in different areas: social, political, economic and technological.

Defending the rights of the victims of this phenomenon has become a constant struggle that unfortunately does not give the positive results that are expected.

Acting on causes is the most viable way to start working to combat this reality that affects everyone.

Overall objective:

Analyze the causes and consequences of modern slavery as well as its impact on society by gathering information related to the topic of interest, seeking to give a clearer perspective on the subject.

Specific objectives:

- Explain why slavery is still a real phenomenon today.

- Relate the consequences of slavery with the impact on current society.

- Propose political alternatives that lead to the solution of this problem.

\section{Justification}

The lack of education; the disinterest and the lack of concern at the individual and social level; the lack of laws or their application that guarantee the equality and protection of people; the complicity; the absence of information and opportunities to report; social conflicts and discrimination based on race or gender, contribute to creating an environment conducive to the exploitation of people by 


\section{traffickers.}

So of course, there is slavery in the world, maybe it is not the same as today, but the feelings of the people are the same, they still feel like a "thing" just like the people who were formerly enslaved.

Today, the number of people affected is alarming, new solutions are needed to solve the problem.

The purpose of this research is to provide a clearer perspective on what is happening in the world and the measures that can be taken to combat this phenomenon. The economic benefits that are obtained with the practice of this activity, as proposed by the UN, are short-term for some since at the same time development is slowing down.

Raising awareness is also one of the aims of this work, it is intended to convey through the facts recorded throughout history and also those that are currently developing what is the role of modern slavery in society, this way of informing It is also a valid way to eradicate it.

\section{Hypothesis}

One of the great causes of slavery is the low importance and great ignorance regarding the affectations in the daily life of the victims of this activity, therefore, it is important to achieve interest and awareness in society about this phenomenon.

Advertising in current media such as social networks, could be a way to reach the population, creating campaigns where the main purpose is to get the support of authorities and people with the ability to guide us to bring the necessary information to the victim population and that it does not remain in legal ignorance, that they know their rights.

\section{Development}

\subsection{Countries Victims of Slavery: Central African Republic and Slavery}

Africa is one of the fastest growing regions. In the center of the continent is the Central African Republic with a population of 4.9 million inhabitants and approximately 52,200 of these inhabitants suffer from slavery, most of the victims are forced into the sex trade, child marriage and combat.

Business opportunities in the Central African Republic are mainly found in the wood and diamond sector.

There are approximately 6000 minors used for combat purposes, they are normally kidnapped to perform forced labor. There are also reports of minors and adult men exploited in the mines of gold and diamonds.

Being a nation with mining activity, workers are needed willing to risk their lives for the extraction of materials, many of the inhabitants of this country do not access this type of work because they do not consider the payment that they are given fair; they need people who are willing to work in these conditions and who do not demand that they be paid too much; They look for people in a situation of very high poverty because they are the ones who meet the profile of the 
perfect employee: they work for a need greater than that of any worker and they are not demanding, only what is necessary to survive day by day.

\subsection{India and Slavery}

India is one of the main countries where high levels of slavery are found in the world. It has a population of 1,311,050,527 inhabitants, of which 14.3 million people are victims of slavery in its different forms. Members of tribes, religious groups and migrants are affected by the modern slavery that normally occurs in textile and embroidered textile, prostitution, mining, agriculture and servitude works (Macro Data, 2017a, 2017b, 2017c).

In 2016 , the GDP figure was $1,987,474 \mathrm{M}$. $€$, with which India is the 7th economy in the ranking of the 196 countries. It is one of the best passes to invest, besides that doing business here can be very feasible due mainly to its manpower and its great wealth in natural resources (Macro Data, 2017a, 2017b, 2017c).

\subsection{Mexico and Slavery}

Mexico is a country with a great diversity of natural resources. Within the country we can find rivers, lakes, forests, minerals, oil. Therefore, its main economic activities revolve around these, such as agriculture, in which Mexico takes full advantage of its lands to produce and thus continue exporting to its main foreign clients.

Mining is another of the economic activities of the country, mainly focused on the extraction of oil throughout the Republic as well as the various precious metals that we find underground (ILO, 2014).

Trade is the economic activity that has the highest number of establishments in the country. Considering the information provided by INEGI, the main articles exported by Mexico are crude oil mainly to the United States, as well as flat screen television and beer among others.

\section{Forms of Slavery}

\subsection{Production Modes and Their Relation to Slavery}

The modes of production are the different ways in which men organize themselves to produce, distribute and consume goods that satisfy their needs; This is the interrelation between productive forces and relations of production that occur in different times that have marked the world (Eumed, 2013).

\subsection{Primitive Community and Its Effect on the Life of Man}

The primitive community is the first way in which men organized themselves in order to satisfy their needs, therefore, it arises with man.

The food, housing and clothing of man depended on what nature offered them, for this reason the first men were nomads; Their diet consisted of fruits and seeds, as well as the meat of the animals they hunted. Their clothing was in some cases nil, some men or women wore garments made with the skin of the 
animals they hunted to feed themselves.

During this period, there was no private property, that is, everything belonged to everyone. Men worked together for the production of goods: they hunted, fished, cooked, collected and even shared lands to live.

\subsection{Slavery as a Mode of Production}

In this mode of production, private property and thus slaves are created and developed as part of the labor force. The property was given on the total product and on the producer (slave). Cultures like the Egyptian, the Babylonian and the Phoenician developed with the mode of slave production; but if we take into account the amount of cultural contributions towards humanity, then the main cultures developed under this mode of production are the Greek and Roman. The slaveholder was the first mode that was based on exploitation according to historical data.

During this mode of production appeared the social classes, in this society arise two: the slavers, that is, the owners of the means of production, and slaves, who were not owners of the means of production.

The slaves did the heavy or overworked jobs that their masters could not or wanted to do, the slaves lacked freedom and were legally bound to their owner, they were treated as objects and not as persons.

\subsection{Feudalism and Its Effect on the Life of Man}

Feudalism is the regime of the middle ages, and this gave rise to capitalism. Its importance is centered in that it established the form from which the system that predominates in most of the world, the capitalist, would be born.

The military leaders distributed the lands of the conquered peoples to their most loyal subjects, making them the dominants of the lands because of this many inhabitants of the small communities were left without protection, so they went to the owners of the lands in search of protection.

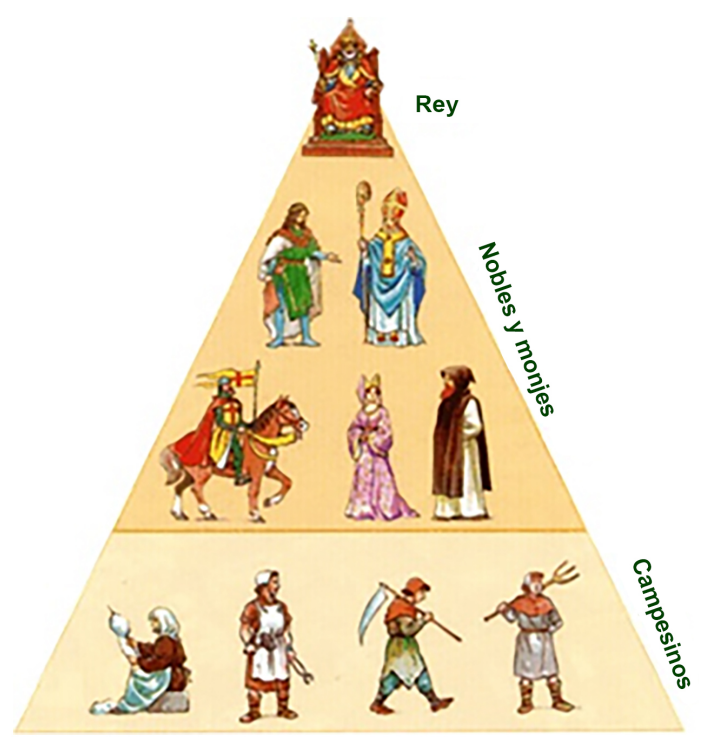


Figure 1 shows the way in which the power was distributed according to the social position in which the man was.

In Figure 1, the main economic activities are agriculture, livestock and commerce. In the slave production mode, social classes are concentrated between masters and slaves, where the former exploit the latter by extracting all possible work from them, giving in return only precarious conditions of subsistence that together with excessive work quickly ends up depleting them and bring them to death.

In the first place was the king, in the second level are the army and the priests, and in the third level are the peasants.

\section{Sexual Slavery}

According to the World Report on Trafficking in Persons conducted by the United Nations in 2012, the most developed countries are those that detect the greatest number of victims (World Organization of the United Nations, 2012).

Sexual slavery is the main cause of this illegal trade in human beings and, since the demand for this type of service is almost always male, women and girls become the main victims of trafficking, constituting an overwhelming $98 \%$. Therefore, trafficking is not a neutral crime in terms of gender, but rather it is a type of gender violence, exercised almost exclusively on women (World Organization of the United Nations, 2012).

The United Nations estimates that around 2.5 million women and children are held in sexual servitude around the world at one point, but many experts believe that the actual number is much higher (World Organization of the United Nations, 2012).

Due to its clandestine nature, it is difficult to determine the extent of sexual slavery. In fact, it is estimated that the number of human beings who are identified victims of trafficking represents only $4 \%$ of the total number of all victims in the world (Mersing, 2014).

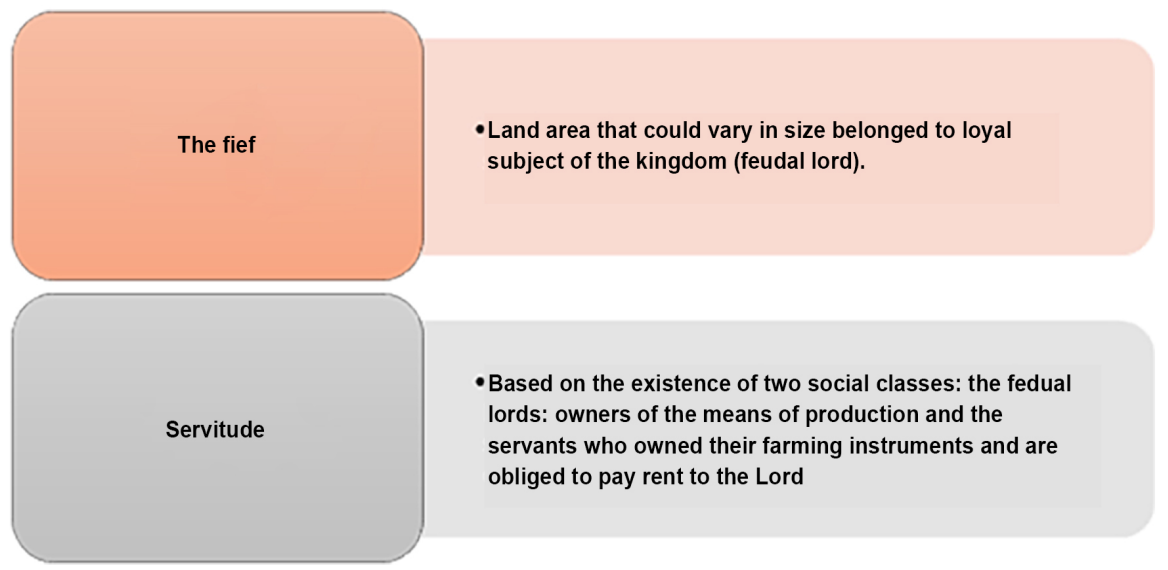

Figure 1. The hierarchical levels of the system. Own elaboration: Source information retrieved from: https://www.forbes.com.mx/esclavitud-moderna/ (Forbes 2013). 


\subsection{Technological Slavery}

Technology keeps changing rapidly, new innovations are presented every day in order to improve and facilitate the life of the human being, however, this can also have disadvantages such as the dependence that users demonstrate to today's technological tools day.

Technology attracts us, entertains us and helps us. It is a fundamental platform for the progress and development of human life. What we can do with it does not seem to have limits (Nevertheless, 2012).

Just as on the one hand it frees us; on the other it can trap us. Just as it connects us with everything and everyone, all the time, it can isolate us, annul us, and suffocate us. Paradoxically, the technological revolution we are witnessing has both the capacity to generate positive feelings and new anxieties and fears.

Recently it was found, in a study carried out in the United Kingdom that more than $50 \%$ of the English population suffers from "nomophobia", that is to say, the irrational fear of leaving home without the mobile phone.

\subsection{Domestic Workers}

Some domestic workers in Mexico face terrible working conditions, discrimination, sexual abuse, psychological, physical abuse, imprisonment or lashes for accusations of theft or adultery, among other things.

The rural areas of Oaxaca, Puebla, Chiapas, Hidalgo, Guerrero and the State of Mexico are the main points of origin of the 2 million domestic workers who are working in some cities of the country, mainly in the Federal District (UNESCO, 2015).

The Center for Support and Training for Domestic Workers (CACEH) has reported in some reports that: "paid domestic work is invisible, minimized and poorly regulated; The workers are mostly women, and in many cases, girls who have left the study to take care of other children, are still under exploitation and poorly paid, and their situation is vulnerable to physical and sexual abuse by men home" (Nisti, 2014).

\subsection{Forced Marriage}

They are stories that exist, closer than you think, they even appear in any social class; however, finding a living source is complicated.

The specialists indicate that the shame factor is installed in this type of cases, so that the testimonies become smoke.

The regime of uses and customs has allowed thousands of Mexicans to be forced to live in marriage with people with whom they did not decide to share their lives.

The problem lies in the lack of information in remote locations. Women are unaware of their rights by accepting the uses and customs of their community. Women and girls who are forced to marry without their consent, have no escape. 
In many cases, they become slaves of their own husbands. Sometimes these marriages are arranged by parents who expect a better future for their children.

\subsection{Slavery: The Evil that Does Not Fade}

When we hear the word slavery, images of remote times come to mind: of galleys, of men and women chained walking on dirt roads, or being sold in the markets like any other merchandise.

In fact, at the legal level, the nineteenth century marked the end of slavery with the Act for the Abolition of the Slave Trade promulgated by the British Parliament in 1807, and that, although it would only prohibit slavery within the borders of the United Kingdom, It would be the trigger for its worldwide ban.

But what if they asked us about slavery today? Can we find in our days, in the times where there is already a letter that includes the fundamental human rights and institutions to defend them, more or fewer slaves? It is not an easy question and your answer requires a thorough analysis. What is clear is that despite being outlawed, slavery continued to exist and evolve.

Figure 2 shows the level of slavery registered in the world.

\subsection{From the Slave to the Enslaved}

Leaving aside the discussions about the definition and the recount of enslaved people in the world, we enter into the task of classification. This is not easy, and as we have seen from the case of the Walk Free Foundation and its inclusion of child soldiers in that category, it is also subject to debate.

In spite of everything we can consider the typologies established by Anti-slavery as a guide to try to better understand the phenomenon of modern slavery. According to this organization, which devotes its efforts to try to combat any type of slavery throughout the world, we could currently find up to six types of slavery (Baena \& Roselló, 2016).

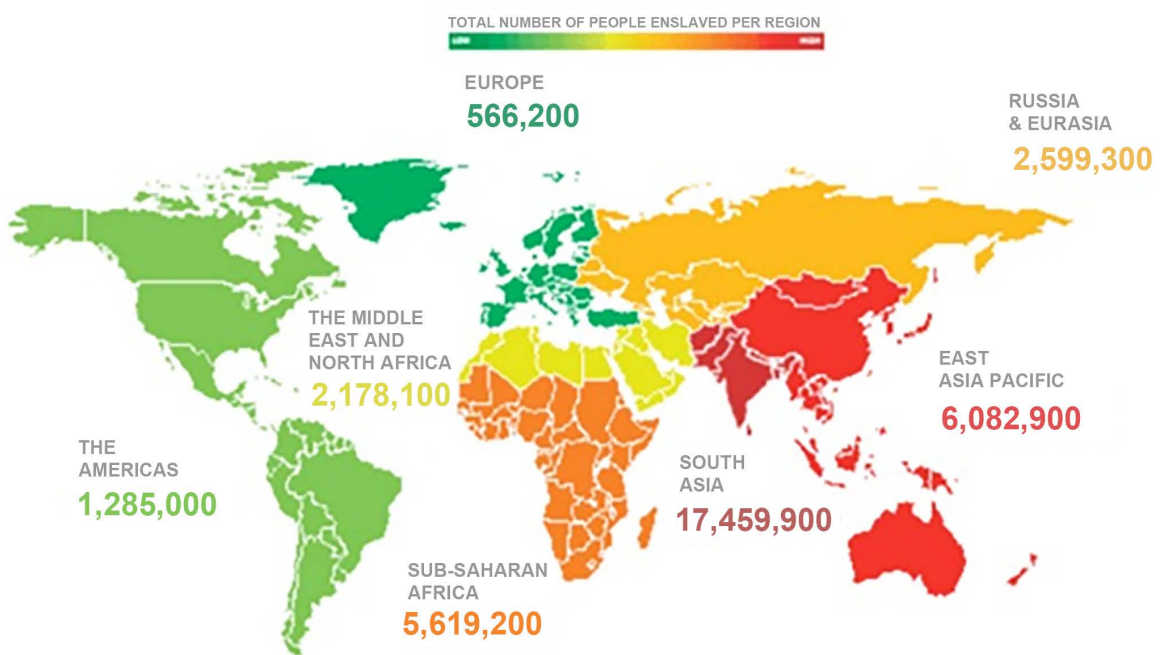

Figure 2. Level of slavery in the world (Image retrieved from: The World Order, 2016). 
The first of these would be that of serfdom, considered the most widespread of all. It is based on the relationship of dependence that is established when one person forces another to work as a form of payment of a debt.

The debt to be paid is constantly increasing, with the debtor being enslaved, often passing on this debt from generation to generation and, therefore, leading to the existence of children who are born slaves.

Being the most widespread type of slavery, we can find it in all parts of the world, but it is especially common in Southeast Asia and the Indian subcontinent, where the bonds of servitude are used, sometimes combined with the hierarchical relations between castes, for jobs of all sectors, from agriculture to industry, as in the case of brick factories (Baena \& Roselló, 2016).

In the second place, we find child slavery, which would affect more than 5.5 million children around the world. It is a type of slavery that does not include only forced labor in agriculture, in factories or in domestic service, but also any type of abusive and coerced use of minors to obtain a profit, either through their prostitution, in the form of pornographic material, criminalization and forced begging ... and of course the recruitment of boys and girls for their participation in armed conflicts (Baena \& Roselló, 2016).

We also have slavery based on the institution of marriage, when it is implemented forcefully and/or when it involves minors.

It would be a type of slavery that, in spite of the existence of male children involved in child marriage processes, mostly affects girls and women.

Although child marriage does not necessarily mean slavery, especially when minors are over 16 , the truth is that, first, it usually means the end of their educational career, in addition to having serious consequences for mental and physical health, especially when violations occur within the matrimony.

On the other hand, what is clear is that marriage is used to cover up cases of slavery and serves as a link to enslave for life the girl who marries and the woman he will become (Baena \& Roselló, 2016).

We also find the obvious case of forced labor. It covers cases in which someone is forced to work against their will under threat of some type of punishment.

Although all types of slavery have some forced labor in their essence, we must distinguish them from it. It involves more than 20 million people around the world, which means that three out of every thousand people employed in the entire world is subjected to forced labor processes. It mainly affects adults (74\%) compared to minors and more to women (55\%) compared to men.

It occurs in all economic sectors, although $90 \%$ occurs in the private economy and in companies, and more than $20 \%$ of them imply sexual exploitationsomething that, again, mainly affects women. In terms of distribution, although it is clearly concentrated in the Asia-Pacific region, where more than 11 million people are subjected to forced labor, we find them in the rest of the regions, including the most developed countries. And it is notable that in $10 \%$ of cases the State, usually through the armed forces, is involved in this phenomenon, for example when they impose it on the inhabitants of rebel regions (Baena \& 


\section{Roselló, 2016).}

In the same way, we would have the case of slavery by descent, often linked to the notion of a "class" or slave "caste".

It is based, in summary, that a person will be a slave if his mother is a slave. It is a bondage that lasts for life and forces people to work for free for the "master", especially in the domestic sphere.

They are treated like properties, being able to be inherited, sold or given away. In addition, they are denied the possibility of working outside of the master-slave relationship, and they are denied all rights, in addition to being subjected to abuse of all kinds by their owners, including forced marriage as a form of concealed prostitution, as is the case of the Wahaya, in Niger.

\section{Looking for the Guilty}

Looking at all these figures, one cannot help but wonder: Who is responsible? Although it is clear, as we have seen, that certain social structures include slavery as one more piece of the hierarchy among individuals, 36 million people are not subject to this yoke just for this reason. In the first place, it is clear that the problems of development, poverty and, of course, wars, constitute an ideal breeding ground for slavery, giving rise to situations of total vulnerability to exploitation and not guaranteeing security for human beings.

The mafias would be one of the actors that most benefit from these situations, trapping migrants in their journey to a better place to live.

Debt bondage, trafficking and labor exploitation are combined in a bloody way in many of these cases. The main victims are, again, women, and the most common fate is their exploitation for sexual purposes, a scourge that no State is spared, including Europeans. It is estimated that this problem would affect 4.5 million women worldwide, being in all continents and countries. Thus, for example, in 2014 only in Spain 14,000 cases would have been uncovered (Baena \& Roselló, 2016).

However, not only criminal groups take advantage of the precariousness to enslave. Large multinational companies, especially those dedicated to the textile sector, produce using labor, often children, in conditions of slavery through a network of subcontractors. Zara, Mango and H\&M are one of many firms accused of using these types of practices, despite the fact that many of the activists and workers who report such situations end up in exile or in jail.

Similar situations are repeated in all sectors, from electronics to agriculture, through mining, the food sector and toy manufacturing (Baena \& Roselló, 2016).

Figure 3 shows the ten main nations where the highest concentration of slaves in the world is found.

And, of course, many states participate directly or indirectly in processes of enslavement, either by not devoting the necessary efforts to combat it, allowing it tacitly within its borders through labor laws that do not protect the rights of workers, or by systematically benefiting from it.

A very striking case is that of Uzbekistan, where every year a process of state 


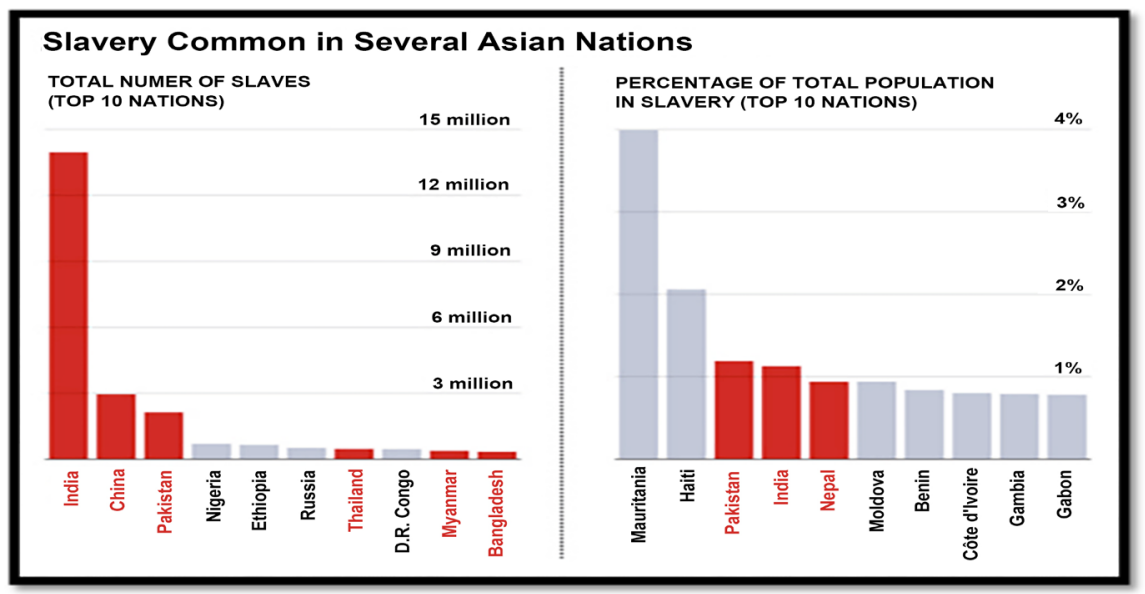

Figure 3. Main nations where the highest concentration of slaves is found (Image retrieved from the source: The World Order, 2016).

labor exploitation is carried out for the cotton harvest, and a number of wellknown Western multinationals are involved again, in which men, women, children are forced and old people to work for free, providing only a plate of food a day.

Thanks to the maintenance of this dynamic, the state enters millions of dollars into its coffers. We are also in Eritrea, where President Issayas Afeworki, a former guerrilla leader who fought for national liberation, has imposed compulsory and indefinite military service, turning the country into a gigantic forced labor camp. Also, various states, such as Myanmar, South Sudan or the Democratic Republic of the Congo use child soldiers among their ranks, which implies that children have been removed from their families and deprived of education to serve in combat, carry out tasks of cleaning or being sexually exploited (Baena \& Roselló, 2016).

In the same way, armed groups in general, whether governmental or rebel forces, constitute another of the actors that carries out slavery processes.

A striking case is that of the Islamic State, which includes trafficking in human beings among its financing methods, and which has subjected thousands of women to sexual exploitation (Baena \& Roselló, 2016).

And, of course, many states participate directly or indirectly in processes of enslavement, either by not devoting the necessary efforts to combat it, allowing it tacitly within its borders through labor laws that do not protect the rights of workers, or by systematically benefiting from it.

A very striking case is that of Uzbekistan, where every year a process of state labor exploitation is carried out for the cotton harvest, and a number of well-known Western multinationals are involved again, in which men, women, children are forced and old people to work for free, providing only a plate of food a day.

Thanks to the maintenance of this dynamic, the state enters millions of dollars into its coffers. We are also in Eritrea, where President Issayas Afeworki, a former guerrilla leader who fought for national liberation, has imposed compulsory 
and indefinite military service, turning the country into a gigantic forced labor camp. Also, various states, such as Myanmar, South Sudan or the Democratic Republic of the Congo use child soldiers among their ranks, which implies that children have been removed from their families and deprived of education to serve in combat, carry out tasks of cleaning or being sexually exploited (Baena \& Roselló, 2016).

In the same way, armed groups in general, whether governmental or rebel forces, constitute another of the actors that carries out slavery processes.

A striking case is that of the Islamic State, which includes trafficking in human beings among its financing methods, and which has subjected thousands of women to sexual exploitation (Baena \& Roselló, 2016).

\section{Conclusion}

The slave trade had drastic effects on societies, mainly by Europeans and Africans in the exchange of goods and some slaves, later became goods with a high added value that generated problems mainly human resources, due to the demand for slaves which progressively hindered economic, political and social development.

The African slave trade caused stability to be lost and internal and external conflicts were generated, on the other hand, the current economic and social problems affecting contemporary Africa have their roots in the Atlantic trade.

\section{Conflicts of Interest}

The authors declare no conflicts of interest regarding the publication of this paper.

\section{References}

Baena, A., \& Roselló, E. (2016). Women in the New Spain. UNAM Website. http://www.historicas.unam.mx/publicaciones/publicadigital/libros/mujeres/nueva espana.html.

Eumed (2013). Dictionary of Political Economy. April 29, 2017, Eumed Website. http://www.eumed.net/cursecon/dic/bzm/m/modo.htm

Forbes (2013). Modern Slavery. May 4, 2017, Forbes Website. https://www.forbes.com.mx/esclavitud-moderna/

International Labor Organization (2014). Forced Labor, Modern Forms of Slavery and Trafficking in Human Beings. May 23, 2017, the International Labor Organization Website. http://ilo.org/global/topics/forced-labour/lang--en/index.htm.

Macro Data (2017a). Central African Republic: Economy and Demography. April 26, 2017, Macro Data Website. http://www.datosmacro.com/paises/republica-centroafricana

Macro Data (2017b). India Population. April 24, 2017, Macro Data Website. http://www.datosmacro.com/demografia/poblacion/india

Macro Data (2017c). India: Economy and Demography. April 25, 2017, Macro Data Website.

http://www.datosmacro.com/paises/india 
Mersing, M. (2014). Sex Slavery: The Sad Fate of Millions of Women and Girls. May 12, 2017, United Explanations Website.

http://www.unitedexplanations.org/2014/11/12/auto-draft/

Nevertheless (2012). Slavery. May 4, 2017, However Website. http://www.sinembargo.mx/20-01-2013/495905

Nisti (2014). Modern Technological Slavery. May 16, 2017, Nistido Website. http://www.nistido.com/2014/05/esclavitud-tecnologica-moderna/

The World Order (2016). Slavery: The Evil that Does Not Fade. May 23, 2017, The World Order Website.

http://elordenmundial.com/2016/02/17/la-esclavitud-el-mal-que-se-desvanece/

UNESCO (2015). New Forms of Slavery. May 5, 2017, UNESCO Website. http://www.unesco.org/new/es/social-and-human-sciences/themes/slave-route/mod ern-forms-of-slavery/

World Organization of the United Nations (2012). The Abolition of Slavery and Its Contemporary Forms. April 27, 2017, United Nations New York and Geneva Website. http://www.ohchr.org/Documents/Publications/slaverysp.pdf 